COSTING:Journal of Economic, Business and Accounting

Volume 4 Nomor 2, Juni 2021

e-ISSN : 2597-5234

\title{
PENGARUH PENJUALAN DAN HARGA POKOK PENJUALAN TERHADAP LABA BERSIH
}

\section{THE EFFECT OF SALES AND COST OF SALES ON NET INCOME}

\author{
Denisa Nurazhari ${ }^{1}$, Dailibas ${ }^{2}$ \\ Universitas Singaperbangsa Karawang,Indonesia ${ }^{1,2}$ \\ denisanurazhari06@gmail.com ${ }^{1}$
}

\begin{abstract}
The problems raised in this study are: analyzing, analyzing and analyzing the analysis and sales and cost of goods sold to net income. The listed companies in the cigarette manufacturing sub-sector were IDX 2011-2019. The number of samples taken were 4 (three) cigarette sub-sector companies from 5 cigarette company populations that had published complete annual financial reports during the study period. The sampling technique used was purposive sampling. This thesis is expected to contribute to the development of accounting, especially financial accounting. The research method used is descriptive quantitative method verivicative with multiple linear regression analysis. Based on the results of data analysis, the results were obtained; Sales have a significant positive effect on net income. And the Sales Price in a partial test has a negative effect on net income, on the same or simultaneous test, Sales and COGS are known to have a significant effect on Net Income.
\end{abstract}

Keywords: Sales, COGS, Net Income,

\begin{abstract}
ABSTRAK
Masalah yang diangkat dalam penelitian ini adalah: untuk mengetahui, menjelaskan dan menganalisis pengaruh secara parsial dan simultan Penjualan dan Harga Pokok Penjualan terhadap Laba Bersih. Pada Emiten perusahaan manufaktur subsector Rokok terdaftar BEI Tahun 2011-2019 Jumlah sampel yang diambil adalah 4 (tiga) perusahaan sub sektor Rokok dari 5 populasi perushaan Rokok yang telah mempublikasikan laporan keuangan tahunan secara lengkap pada periode penelitian. Teknik sampling yang digunakan adalah Purposive Sampling. Skripsi ini diharapkan dapat memberikan sumbangan bagi pengembangan bidang akuntansi khususnya akuntansi keuangan. Metode penelitian yang digunakan adalah metode kuantitatif deskriptif verivikatif dengan analisis regresi linear berganda. Berdasarkan hasil analisis data penelitian diperoleh hasil dimana; penjualan secara signifikan berpengaruh positif terhadap Laba bersih .dan Harga Pokok Penjualan dalam pengujian parsial memiliki pengaruh negative terhadap LAba bersih, pada uji simultan atau bersamaan sama, Penjualan dan HPP diketahui secara signifikan berpengaruh terhadap Laba Bersih.
\end{abstract}

Kata Kunci: Penjualan , HPP , Laba Bersih,

\section{PENDAHULUAN}

Pertumbuhan

Indonesia masih kategori ekonomi di termasuk dalam ekonomi Negara yang berkembang, dan perkembangan ekonomi suatu Negara dapat diukur dengan berbagai cara. Salah satunya dengan mengetahui tingkat 
perkembangan dunia pasar modal dan industi-industri sekuritas pada Negara tersebut. Persaingan di dunia usaha saat ini sangat pesat, terutama di sektor industri dan kimia, hal ini menyebabkan setiap perusahaan berupaya untuk dapat mempertahankan kelangsungan hidup perusahaannya masing-masing. Usaha yang dilakukan oleh perusahaan antara lain dengan menyesuaikan diri terhadap perubahan-perubahan yang terjadi di dalam maupun di luar perusahaan, serta mengupayakan agar setiap sumber daya yang dimiliki oleh perusahaan dapat digunakan secara efektif dan efisien

Didirikannya sebuah perusahaan pada umumnya mempunyai suatu tujuan. Tujuan tersebut yaitu untuk memperoleh laba yang sebesar-besarnya demi menjaga kelangsungan hidup perusahaan. Hal ini agar segala kegiatan dalam perusahaan dapat berlangsung dengan baik sehingga mampu bersaing dengan perusahaan-perusahaan yang sejenis. Di era globalisasi sekarang ini tingkat persaingan sangat tinggi sehingga hanya badan usaha yang memiliki kinerja atau performa yang baik yang akan bertahan. Dalam persaingan usaha yang semakin kompetitif perusahaan dituntut untuk semakin efisien dalam menjalankan aktivitasnya, terlebih dalam kondisi ekonomi saat ini yang penuh ketidakpastian dan krisis ekonomi yang melanda Indonesia sangat berat serta merusak berbagai sektor dan perekonomian, sehingga perlu mengoptimalkan sumber daya yang dimiliki (Wisesa, et.al, 2015).

Dengan laba ini membuat perusahaan tumbuh dan berkembang, bisa menggunakan kemampuan yang lebih besar, bisa memberikan tingkat kepuasan yang lebih besar dapa konsumen, dan perusahaan bisa memperkuat kondisi perekonomian secara keseluruhan. Bahwa Laba bersih adalah laba yang berasal dari transaksi pendapatan, beban, keuntungan dan kerugian. Transaksi- transaksi ini ditaksirkan dalam laporan laba- rugi. Laba dihasilkan dari selisih antara sumber daya masuk (pendapatan dan keuntungan) dengan sumber daya keluar (beban dan kerugian) selama periode tertentu (Simamora, 2013).

Untuk memperoleh laba maksimum, perusahaan harus menghasilkan produk dengan cara dan dalam bentuk volume penjualan sehingga akhirnya akan didapatkan pendapatan penjualan. Volume penjualan diartikan sebagi seluruh jenis barang yang disediakan/diserahkan kepada konsumen atau pelanggan tanpa memandang jumlah rupiah relative tiap jenis produk tersebut ataupun sering tidaknya prosuk tersebut dihasilkan.

Industri rokok kretek sebagai salah satu industri yang ada di Indonesia telah memberikan konstribusi bagi negara Indonesia berupa masukan berbagai pajak. Seperti yang terdapat pada APBN (Anggaran Pendapatan Belanja Negara), pajak cukai rokok merupakan bagian dari pada penerimaan dalam negeri, dimana pada pembuatan APBN setiap tahunnya makan kebijakan tarif cukai merpakan salah satu komponen kebijakan fiskal yang dibuat oleh pemerintah.

Ketua Asosiasi Petani Tembakau Indonesia (APTI) Soeseno sebelumnya mengatakan petani khawatir kenaikan cukai yang terlalu tinggi membuat hasil panen tembakau yang dibeli oleh pabrik rokok berkurang. Pasalnya ada kemungkinan produsen rokok mengurangi produksi jika konsumen berkurang karena imbas harga rokok semakin mahal. (idnfinancial.com)

Pada teorinya menyatakan Penjualan adalah suatu usaha yang terpadu untuk mengembangkan rencana- rencana strategis yang 
diarahkan pada usaha pemuasan kebutuhan dan keinginan pembeli guna mendapatkan penjualan yang menghasilkan laba (Priyatno, 2013). Maka dari itu penjualan memiliki pengaruh yang searah dengan laba bersih, karena penjualan dapat meningkatakan laba bersih.

Dengan bekurangnya pembelian tembakau oleh perusahaan industri rokok yang disebabkan karena kenaikan cukai yang tinggi akan berpengaruh terhadap harga pokok penjualan dan penjualan, dimana harga rokok akan naik dan konsumen pun berkurang.

Kondisi belanja yang menurun dan ditambah dengan adanya kenaikan cukai perlu adanya pengendalian yag menyebab penurunan produksi yang kemudian akan menimbulkan kerugian kepada industri rokok. Jika sudah rugi industri akan dengan terpaksa harus mengurangi biaya produksi yang salah satunya adalah dengan melakukan efisiensi tenaga kerja dan memicu terjadinya PHK masal. Dan negara juga akan merugi karena setoran pajak dan cukai industri rokok akan berkurang yang berarti pemasukan negara juga berkurang.

\section{METODE PENELITIAN}

Metode penelitian yang digunakan didalam penelitian ini adalah metode penelitian kuantitaif verifikatif. Pendekatan verifikatif pada dasarnya ingin menguji kebenaran dari hipotesis yang dilaksanakan melalui pengumpulan data. Pendekatan verifikatif bertujuan untuk menjawab Pengaruh Penjualan dan Harga Pokok Penjualan terhadap Laba Bersih Pada Perusahaan Industri Manufaktur Sektor Industri Barang Konsumsi Sub Rokok yang Terdaftar di Bursa Efek Indonesia (BEI) Tahun 20112019.

Dalam penelitian ini terdapat satu variabel terikat dan dua variabel bebas.
Variabel bebas dalam penelitian ini adalah Penjualan (X1) dan Harga Pokok Penjualan (X2), sedangkan variabel terikat dalam penelitian ini adalah Laba Bersih (Y).

Populasi yang digunakan dalam penelitian ini adalah laporan keuangan tahunan perusahaan sub rokok yang terdaftar di Busra Efek Indonesia (BEI) di mulai dari tahun 2011 sampai tahu 2019, yaitu sebanyak 5 perusahaan.

Teknik sampling yang digunakan dalam penelitian ini ialah purposive sampling. Adapun Kriteria yang dilakukan dalam penelitian ini adalah sebagai berikut, Perusahaan sub sektor rokok yang terdaftar di Bursa Efek Indonesia (BEI), Perusahaan sub sektor rokok yang terdaftar secara berturut-turut di Bursa Efek Indonesia (BEI) tahun 2011-2019, dan Telah menerbitkan laporan keuangan secara lengkap yang berakhir 31 Desember selama tahun 2011-2019.

Sehingga sampel yang diambil adalah 4 perusahaan rokok yang terdaftar di Bursa Efek Indonesia dengan laporan keuangan 8 tahun dari tahun 2011-2019. Sehingga sampel yang digunakan sebanyak 32 sampel.

Sumber data yang digunakan oleh peneliti didapatkan melaui internet melalui situs resmi Bursa Efek Indonesia yaitu www.idx.co.id. Data yang diperoleh berupa data laporan keuangan perusahaan selama periode 2011 sampai dengan 2019 mengenai Penjualan, Harga Pokok Penjualan dan Laba Bersih serta data lainnya yang dapat menunjang penelitian ini.

Teknik pengumpulan data dilakukan dengan melakukan telaah pustaka, eksplorasi dan mengkaji berbagai literatur pustaka. Seperti jurnaljurnal ilmiah, makalah serta sumber informasi lain yang memuat pembahasan dan permasalahan yang berkaitan dengan penelitian. Yaitu penelitian yang 
dilakukan dengan cara mempelajari dan memahami data yang diperoleh dari berbagai literature, seperti buku-buku cetak, artikel website/internet yang berkaitan dengan pembahasan penelitian ini.

\section{HASIL DAN PEMBAHASAN}

Tabel 1 Analisis Regresi Linier Berganda

\begin{tabular}{llrr}
\hline Model & \multicolumn{2}{c}{ Unstandardized Coefficients } \\
\cline { 2 - 4 } & & \multicolumn{1}{c}{ B } & Std. Error \\
\hline 1 & (Constant) & 7866,350 & 2467,065 \\
\cline { 2 - 3 } & Penjualan &, 172 &, 014 \\
\cline { 2 - 3 } HPP & $-1163,549$ & 308,367 \\
\hline
\end{tabular}

Sumber : Data Olahan (2020)

Berdasarkan uji regresi linier berganda dapat dilihat bahwa nilai konstanta sebesar 7866,350, yang berarti jika penerapan variabel independen konstan, maka dapat meningkatkan variabel dependen sebesar 7866,350. Dari hasil tersebut, dapat dibuat persamaan regresi sebagai berikut,

Berdasarkan persamaan yang telah dibuat diketahui bahwa :

1. Nilai koefisien regresi penjualan sebesar 0,172 berarti bahwa jika penjualan terjadi kenaikan satu poin, maka nilai laba bersih akan meningkat 0,172 . Hal ini menunjukkan jika penjualan meningkat maka laba bersih akan meningkat.

2. Nilai koefisien regresi harga pokok penjualan (HPP) sebesar -1163,546 berarti bahwa jika harga pokok penjualan terjadi kenaikan satu poin, maka nilai laba bersih akan menurun 1163,546. Hal ini menunjukkan jika harga pokok penjualan meningkat maka laba bersih akan menurun.

\section{Hasil Koefisien Determinasi}

Koefisien determinasi (R2) memiliki nilai antara satu dan nol . nilai koefisien determinasi (R Square) sebesar 0,923 . Besarnya angka koefisien determinasi ( $\mathrm{R}$ Square) 0,923 sama dengan 92,3\%. Angka tersebut mengandung arti bahwa penjualan dan harga pokok penjualan berpengaruh terhadap laba bersih sebesar 92,3\%. Sedangkan sisanya yaitu 7,3\% (100\%$92,3 \%$ ) dipengaruhi oleh variabel lain yang tidak diteliti dalam model regresi ini.

\section{Hasil Pengujian Hipotesis Uji Parameter Individual (Uji t)}

Tabel 2. Hasil Uji Hipoteses Secara Parsial

\begin{tabular}{lcc} 
Model & $\mathrm{t}$ & Sig. \\
\hline (Constant) & 3,189 & .003 \\
\hline Penjualan & 12,725 & .000 \\
\hline HPP & $-3,773$ & .000
\end{tabular}

Sumber : Data Olahan (2020)

Dengan menggunakan signifikasi $5 \%$ atau 0,05 dan menggunakan uji 2 sisi diperoleh nilai $\mathrm{t}$ tabel $(\mathrm{dF}=\mathrm{n}-\mathrm{k}$; dua sisi $(0,05))$ atau $(\mathrm{dF}=36-2=34$, uji dua sisi $0,05)$ jadi nilai t tabel sebesar 1.701 .

Nilai t hitung Variabel X1 sebesar 12,725. Jika dibandingkan dengan nilai $t$ tabel yaitu sebesar 1.701 maka akan memperoleh hasil nilai $\mathrm{t}$ hitung $>\mathrm{t}$ tabel atau sama dengan 12,725 $>1.701$. Serta diperoleh nilai signifikansi sebesar 0,000 yaitu lebih kecil dari 0,05 . Sehingga dapat disimpulkan bahwa $\mathrm{H} 0$ ditolak dan H1 diterima. Dengan demikian, dapat disimpulkan bahwa secara parsial penjualan berpengaruh terhadap laba bersih.

Nilai t hitung variabel X2 sebesar negative 3,773. Jika dibandingkan dengan nilai t tabel yaitu sebesar 1.701 maka akan memperoleh hasil nilai $t$ hitung $>\mathrm{t}$ tabel atau sama dengan negative 3,3773 $>1.701$. Serta diperoleh nilai signifikansi sebesar 0,001 yaitu lebih kecil dari 0,05. Sehingga dapat disimpulkan bahwa $\mathrm{H} 0$ ditolak dan $\mathrm{H} 2$ diterima. Dengan demikian, dapat disimpulkan bahwa secara parsial harga 
pokok penjualan berpengaruh negatif terhadap laba bersih.

Uji Simultan (Uji f)

Tabel 3. Hasil Uji Hipotesis Secara Bersamasama (Uji f)

\begin{tabular}{|c|c|c|}
\hline Model & $\mathrm{F}$ & Sig. \\
\hline 1 Regression & 197,24 & $.000^{\mathrm{b}}$ \\
\hline
\end{tabular}

Sumber : Data Olahan (2020)

Berdasarkan hasil pengujian secara simultan, yaitu diperoleh nilai Fhitung sebesar 197,244. Adapun nilai Ftabel pada tingkat signifikansi $5 \%$ dan derajat kebebasan $\mathrm{dF} 1$ (variabel bebas) = 2 dan $\mathrm{dF} 2(\mathrm{n}-\mathrm{k})=34$ maka Ftabel yang didapat $F(2 ; 34)=3,34$. Nilai $F$ hitung dengan $\mathrm{F}$ tabel selanjutnya dibandingkan, sehingga diperoleh nilai $\mathrm{F}$ hitung $>\mathrm{F}$ tabel yaitu 197,244 > 3,34. Nilai signifikasi sebesar 0,000 lebih kecil dari 0,05. Sehingga H0 ditolak dan $\mathrm{H} 3$ diterima. Dengan demikian dapat disimpulkan bahwa penjualan dan harga pokok penjualan secara bersama-sama berpengaruh terhadap laba bersih pada perusahaan sub-sektor yang terdaftar di Bursa Efek Indonesia Periode 2011-2019.

\section{Pengaruh Penjualan terhadap Laba Bersih}

Berdasarkan hasil pengolahan data diatas didapat nilai $\mathrm{t}$ hitung sebesar 12,725. Jika dibandingkan dengan nilai $t$ tabel yaitu sebesar 1.701 maka akan memperoleh hasil nilai $\mathrm{t}$ hitung $>\mathrm{t}$ tabel atau sama dengan $12,725>1.701$. Serta diperoleh nilai signifikansi sebesar 0,000 yaitu lebih kecil dari 0,05 .

Berdasarkan hasil diatas, maka hasil penelitian menunjukkan bahwa penjualan berpengaruh terhadap laba bersih, adanya hubungan yang erat mengenai penjualan terhadap peningkatan laba bersih perusahaan dalam hal ini dapat dilihat pada laporan laba rugi perusahaan, karena dalam hal ini laba akan timbul jika penjualan produk lebih besar dibandingkan dengan biaya-biaya yang dikeluarkan. Penjualan berpengaruh secara signifikan terhadap laba bersih karena bila penjualan hasil produksi perusahaan meningkat maka diharapkan akan menaikkan laba bersih pula, selama hasil penjualan atau pendapatan tersebut lebih besar daripada biaya yang dikeluarkan. Namun, pada praktik di lapangan hasil penelitian di atas merupakan fakta yang terjadi pada beberapa perusahaan subsector rokok yang dimana penjualannya terus naik tetapi tidak di imbangidengan peningkatan laba bersih. Adapun faktor yang menyebabkan laba bersih menurun antara lain naiknya beban penjualan dan administrasi umum.

Hal ini sejalan dengan penelitian Susilawati \& Asep (2018) yang mengemukakan bahwa "penjualan berpengaruh terhadap laba bersih pada pada PT Indocement Tunggal Prakarsa" dan di Dukung Kembali oleh Akbar \& Astuti (2017) dan Nyoman (2016). Namun tidak sejalan dengan penelitian Yuliman, et.al (2016) yang mengemukakan bahwa "penjualan tidak berpengaruh terhadap laba bersih pada PT. Aneka Tambang,Tbk".

\section{Pengaruh HPP terhadap Laba Bersih}

Berdasarkan hasil pengolahan data diatas didapat nilai t hitung sebesar 3,3773. Jika dibandingkan dengan nilai $t$ tabel yaitu sebesar -1.701 maka akan memperoleh hasil nilai $\mathrm{t}$ hitung $>\mathrm{t}$ tabel atau sama dengan $-3.3773>-1.701$. Serta diperoleh nilai signifikansi sebesar 0,000 yaitu lebih kecil dari 0,05.

Berdasarkan hasil pengolahan data diatas didapat harga pokok penjualan berpengaruh negatif terhadap laba bersih, Biaya pembelian material 
pada supplier mencakup sejumlah biaya yang dikeluarkan perusahaan supplier untuk melaksanakan proses produksinya. Oleh karena untuk memperoleh dan mengolah bahan-bahan menjadi produk jadi dalam kegiatan proses produksi diperlukan dana atau biaya-biaya, maka untuk menutup pengeluaran biaya-biaya tersebut biasanya perusahaan memperhitungkannya dalam penetapan harga pokok penjuakan. Kebijakan manajemen dalam penetapan harga jual produk belum dapat memadai jika hanya ditujukan untuk mengganti atau menutup semua biaya yang telah dikeluarkan, tetapi juga harus dapat menjamin adanya laba yang diharapkan, meskipun keadaan yang dihadapi tidak menguntungkan.

Walaupun permintaan dan penawaran biasanya merupakan faktor yang menentukan dalam penetapan harga, namun penetapan harga jual produk yang menguntungkan akan tergantung pula pada pertimbangan mengenai biaya. Bila perusahaan dapat menekan biaya produksi sampai pada batas minimal maka nilai keuntungan yang diperoleh perusahaan akan meningkat.

Hasil pengujian menunjukkan bahwa hasil penelitian ini sesuai dengan hasil penelitian yang dilakukan oleh Nurfaidah (2017), mengemukakan bahwa "harga pokok penjualan berpengaruh negative terhadap laba bersih pada perusahaan subsector makanan dan minuman yang terdaftar di BEI tahun 2014-2016. Namun berbeda dengan penelitian dari Ear (2017) dan Retno (2018) yang menyimpulkan bahwa biaya produksi tidak berpengaruh signifikan terhadap laba bersih.

\section{Pengaruh Penjualan dan HPP terhadap Laba Bersih}

Berdasarkan hasil pengolahan data diatas didapat, Nilai $F$ hitung 197,244, sehingga diperoleh nilai $F$ hitung > F tabel yaitu 197,244 > 3,34. Nilai signifikasi sebesar 0,000 lebih kecil dari 0,05 .

Berdasarkan hasil pengolahan data diatas didapat penjualan dan harga pokok penjualan secara bersama-sama berpengaruh terhadap laba bersih, Laba merupakan tujuan perusahaan, di mana dengan laba perusahaan dapat memperluas usahanya. Kemampuan perusahaan untuk memperoleh laba merupakan salah satu petunjuk tentang kualitas manajemen serta operasi perusahaan tersebut, yang berarti mencerminkan nilai perusahaan. Perusahaan mampu menghasilkan penjualan yang tinggi dan meminimalkan harga pokok penjualan yang dikeluarkan. Hasil penjualan dan harga pokok penjualan yang dikendalikan dengan baik sehingga selama periode berjalan laba yang diperoleh cenderung mengalami kenaikan.

Hasil pengujian menunjukkan bahwa hasil penelitian ini sesuai dengan hasil penelitian yang dilakukan oleh Retno \& Eka (2018), mengemukakan bahwa "adanya pengaruh simultan antara pharga pokok produksi, biaya operasional, dan penjualan bersih terhadap laba bersih pada perusahaan sektor industri tekstil dan garmen yang terdaftar di BEI tahun 2012-2016".

\section{PENUTUP}

\section{Kesimpulan}

Berdasarkan hasil penelitian dan pembahasan yang dilakukan oleh penulis, maka dapat diambil beberapa kesimpulan, yaitu :

1. Penjualan Berpengaruh Positif Terhadap Laba Bersih

2. HPP Berpengaruh Negatif Terhadap Laba Bersih

3. Penjualan Dan HPP Berpengaruh Secara Simultan Terhadap Laba Bersih. 


\section{Saran}

Penelitian ini memiliki keterbatasan hanya meneliti variabel Penjualan dan HPP saja sebagai variabel yang mempengaruhi Laba Bersih. Untuk peneliti selanjutnya, diharapkan dapat menggunakan faktor-faktor internal lainnya yang mempengaruhi LAba Bersih selain variabel yang digunakan oleh peneliti. Dan diharapkan peneliti selanjutnya bisa menambah periode waktu penelitian, dan faktor faktor lain baik internal maupun eksternal agar hasil yang diperoleh mempunyai cakupan yang lebih luas dan hasil yang akurat serta memperluas objek penelitian, sehingga tidak hanya terbatas pada satu perusahaan saja

\section{DAFTAR PUSTAKA}

Akbar, A. S. \& Astuti, W. A. (2017). Pengaruh Penjualan dan Biaya Produksi terhadap Laba Bersih (Survei pada Perusahaan Manufaktur Sektor Aneka Idustri Sub Sektor Otomotif dan Komponen yang Terdaftar di Bursa Efek Indonesia (BEI) Tahun 2011-2016). Skripsi. Universitas Komputer Indonesia Bandung.

Ear, D, Y. (2017). Pengaruh Biaya Produksi, Biaya Operasional dan pendapatan Usaha terhadap Laba bersih. e-Journal Bisma Universitas Pendidikan Ganesha

Nurfaidah, A. (2017). Harga Pokok Penjualan dan Volume Penjualan terhadap laba bersih pada perusahaan subsector makanan dan minuman yang terdaftar di BEI tahun 2014-2016. Universitas Hasanuddin.
Nyoman, N. Y. (2016). Pengaruh Penjualan dan Modal Sendiri Terhadap Laba pada UD Aneka Jaya Motor di Singaraja periode 2012-2014. e-Journal Bisma Universitas Pendidikan Ganesha.

Priyatno, D. (2013). Cara Kilat Belajar Analisis Data dengan SPSS 20. Yogyakarta: Andi Offset.

Retno, A. R \& Eka, S. W. (2018). Pengaruh Penjualan, Beban Pokok Penjualan, Pajak Dan Biaya Keuangan Terhadap Laba Rugi Perusahaan Jasa Telekomunikasi. Jurnal Ekonomi Manajemen.

Simamora, H. (2013). Pengantar Akuntansi II. Jakarta: Bumi Aksara.

Susilawati, E. \& Asep M. (2018). Pengaruh Penjualan dan Biaya Operasional terhadap Laba Bersih PT Indocement Tunggal Prakarsa (Persero) Tbk Periode 2010-2017. Jurnal Saintifik Manajemen dan Akuntansi.

Wisesa, Z., \& Suwena, K. R. (2015). Pengaruh Volume Penjualan Mente dan Biaya Operasional terhadap Laba Bersih pada UD Agung Esha Tahun 2013. Jurnal Pendidikan Ekonomi Undiksha.

Yuliman, A. (2016). Pengaruh penjualan bersih dan Biaya Produksi terhadap Laba Bersih pada PT. Aneka Tambang,Tbk. Jurnal Ilmiah Akuntansi 